\title{
Faktor Risiko Kejadian Recurrent Respiratory Infection pada Anak Usia 2-5 Tahun
}

\author{
Nopriyan Pujokusuma ${ }^{1}$, Eti P. Pamungkasari ${ }^{2}$, Setyo S. Rahardjo ${ }^{3}$ \\ 1.Program pendidikan Dokter, Fakultas Kedokteran Universitas Sebelas Maret \\ 2.Bagian Ilmu Kesehatan Masysrakat Fakultas Kedokteran Universitas Sebelas Maret \\ 3.Bagian Farmakologi Fakultas Kedokteran Universitas Sebelas Maret
}

Korespondensi: nopriyanp@gmail.com

\begin{abstract}
ABSTRAK
Pendahuluan: Infeksi Saluran Pernapasan Akut (ISPA) merupakan penyakit dengan morbiditas dan mortalitas tinggi pada balita. ISPA yang terjadi berulang selama lebih dari 5 kali dalam satu tahun dikatakan sebagai Recurrent Respiratory Infection (RRI). Sebagian besar kematian akibat ISPA berasal dari jenis ISPA yang berkembang dari penyakit yang dapat dicegah dengan imunisasi. Tujuan penelitian ini adalah untuk mengetahui hubungan antara status imunisasi, status gizi, kepadatan hunian, asap rokok, tingkat pendidikan ibu dan tingkat pendapatan keluarga dengan kejadian RRI pada balita usia 2-5 tahun di Wilayah Kerja Puskesmas Sibela, Surakarta.

Metode: Penelitian bersifat observasional analitik cross-sectional. Sampel adalah anak usia 2 - 5 tahun di wilayah kerja Puskesmas Sibela, Surakarta. Sampel diambil secara cluster sampling sebanyak 121 anak, orang tua diwawancarai menggunakan kuesioner, dan dilakukan pengukuran tinggi dan berat badan anak. Data riwayat imunisasi anak dan diagnosis ISPA dalam satu tahun didapatkan dari buku Kesehatan Ibu dan Anak (KIA) dan data Sistem Informasi Manajemen Puskesmas (SIMPUS). Analisis data dengan analisis bivariat (chi-kuadrat) dan analisis multivariat (regresi logistik).

Hasil: Hasil chi-kuadrat menunjukkan terdapat hubungan bermakna antara status imunisasi yang tidak lengkap dengan kejadian RRI $(p=0,000)$ dan nilai $\mathrm{OR}=18,774$. Dari hasil analisis multivariat didapatkan hubungan bermakna antara status imunisasi dengan kejadian RRI ( $\mathrm{p}=0,000 ; \mathrm{OR}=21,3)$.

Kesimpulan: Status imunisasi tidak lengkap secara bermakna berpengaruh dalam meningkatkan kejadian RRI 21,3 kali pada anak usia 2-5 tahun dibandingkan anak dengan imunisasi lengkap. Status gizi, kepadatan hunian, adanya perokok, tingkat pendidikan ibu, dan tingkat pendapatan keluarga tidak memiliki hubungan bermakna dengan kejadian RRI.
\end{abstract}

Kata Kunci: Status Imunisasi, ISPA, ISPA.

\begin{abstract}
Introduction: Acute Respiratory Infection (ARI) is the most prevalent disease with high mortality and morbidity on infant. ARI that happens more than five times annually is called Recurrent Respiratory Infection (RRI). Some mortality of ARI comes from kind of ARI that developed from diseases that could be prevented by immunization. This study aimed to find correlation between immunization status, nutritional status, crowding, smoker in house, mother education level, family income level and RRI incident on children age 2-5 years old in Sibela Primary Health Care (PHC) work area, Surakarta.

Methods: This was an observational analytic study with cross-sectional approach. Sample for this study was children age 2-5 years old from Sibela PHC work area, Surakarta. Sample was taken by cluster sampling method as much as 121 children, the parent interviewed using questioner and children was measured for their height and weight. Data of immunization history was obtained from Kesehatan Ibu dan Anak (KIA)
\end{abstract}


Book and PHC data information system for ARI diagnosis. Data was analyzed using chisquare and logistic regression.

Result: Chi-square result shows significant correlation between incomplete immunization status and incident of $R R I(p=0,000)$ and $O R=18,774$. Logistic regression results shows significant correlation between immunization status and incident of RRI ( $p=0,000$; OR=21,3).

Conclusions: Incomplete immunization status significantly correlate to increasing RRI incident 21,3 times on children age 2-5 years old than children which acquired complete immunization status. Nutritional status, crowding, smoker in house, mother educational level, and family income level has no significant correlation with RRI incidence.

Keywords: Immunization Status, RRI, ARI

\section{PENDAHULUAN}

Infeksi saluran napas akut (ISPA) merupakan salah satu penyebab kematian utama pada anak usia dibawah lima tahun. ${ }^{1}$ ISPA terjadi karena kumpulan infeksi yang luas dan heterogen, meliputi infeksi bakterial, infeksi viral dan infeksi yang disebabkan oleh etiologi penyakit lainnya. ${ }^{2}$ ISPA diderita oleh $13,8 \%$ balita di Indonesia. ISPA dapat terjadi berulang-ulang dalam kurun waktu yang singkat. ${ }^{3}$ Seorang anak dikatakan mengalami Recurrent Respiratory Infection (RRI) ketika menderita ISPA 6 kali atau lebih dalam kurun waktu 1 tahun. ${ }^{4}$

Beberapa penelitian telah dilakukan
untuk melihat faktor-faktor yang memengaruhi tingginya prevalensi ISPA, diantaranya adalah ASI eksklusif tidak lengkap 6 bulan, ${ }^{5}$ berat bayi lahir rendah, kurangnya durasi pemberian ASI eksklusif, crowding - penghuni rumah lebih dari tujuh orang dalam satu rumah, paparan polusi udara dalam ruang, kekurangan gizi (BB/U kurang dari 2 SD), infeksi HIV, dan imunisasi tak lengkap. ${ }^{6}$

Hal senada ditemukan dalam hasil penelitian oleh Lestari et $\mathrm{al}^{7}$ tentang dampak status imunisasi anak balita di Indonesia terhadap kejadian penyakit. status imunisasi dasar lengkap berpengaruh terhadap menurunkan angka kejadian dari penyakitpenyakit dapat dicegah dengan imunisasi (PD3I) dan komplikasinya seperti diare dan pneumonia. Dimana pneumonia itu sendiri merupakan salah satu bentuk dari ISPA yang merupakan penyebab kematian tersering ketiga di dunia. ${ }^{8}$

Studi terdahulu menunjukan adanya hubungan antara status imunisasi dasar dengan kejadian pneumonia yang merupakan salah satu bentuk dari ISPA. Namun, walaupun terjadi peningkatan pada cakupan imunisasi, ISPA masih merupakan salah satu penyakit dengan angka kesakitan dan angka kematian terbesar di Indonesia. Oleh karena itu, tujuan peneliti melakukan penelitian ini adalah untuk mengetahui hubungan status imunisasi, status gizi, kepadatan hunian, asap rokok, tingkat pendidikan dan tingkat pendapatan keluarga dengan kejadian RRI pada balita usia 2-5 tahun di Wilayah Kerja Puskesmas Sibela, Surakarta, Jawa Tengah.

\section{METODE}

Jenis penelitian ini adalah observasional analitik dengan pendekatan cross sectional. Penelitian ini berlokasi di Wilayah Kerja Puskesmas Sibela, Surakarta. Populasi sasaran dalam penelitian ini adalah anak usia 2-5 tahun. Populasi sumber dalam penelitian ini adalah anak usia 2-5 tahun di wilayah kerja Puskesmas Sibela, Kecamatan Jebres, Surakarta tahun 2018. Subyek Penelitian adalah anak usia 2-5 tahun yang pernah menderita ISPA dalam satu tahun sebelum pengambilan data di wilayah kerja Puskesmas Sibela dengan karakteristik kriteria inklusi dan eksklusi. Kriteria inklusinya adalah anak 
dengan ibu atau pengasuhnya sejak lahir yang memiliki catatan imunisasi atau Kartu Ibu dan Anak (KIA) dan bersedia menjadi responden. Kriteria ekslusinya adalah anak dengan penyakit kongenital yaitu anak dengan gangguan perkembangan dan anak dalam pengobatan imunosupresan jangka Panjang.

Besar sampel pada penelitian ini menggunakan rumus untuk penelitian analitik kategorik tidak berpasangan dengan rumus sebagai berikut:

$n=\left(\frac{Z_{\propto \alpha} \sqrt{2 P Q}+Z_{\beta} \sqrt{P_{1} Q_{1}+P_{2} Q_{2}}}{P_{1}-P_{2}}\right)^{2}$

Dengan rumus tersebut didapatkan besar sampel 109,62 anak, untuk menghindari terjadinya drop out atau missing dari responden maka sampel perlu ditambahkan $10 \%$ dari besar sampel yang diperoleh. Besar sampel diperlukan setelah penambahan $10 \%$ menjadi 120,58 yang kemudian dibulatkan menjadi 121 orang.

Pengambilan sampel dalam penelitian ini menggunakan teknik probability sampling dengan metode cluster random sampling. Pemilihan suatu cluster, dalam hal ini adalah posyandu, dilakukan secara acak dengan sistem undian untuk memperkecil kemungkinan adanya bias, sehingga diperoleh sampel yang representatif (mewakili).

Dalam penelitian ini variabel bebasnya adalah status imunisasi balita dengan usia 2-5 tahun di Wilayah Kerja Puskesmas Sibela, Surakarta dan kejadian RRI merupakan variabel terikat. Variabel luar yang masih diteliti meliputi kepadatan hunian, adanya perokok dalam rumah, status gizi balita, tingkat pendapatan keluarga dan tingkat pendidikan ibu.

Status imunisasi balita diukur berdasarkan catatan dalam KIA tentang riwayat imunisasi dasar anak. Status imunisasi dasar dalam penelitian ini dikatakan lengkap apabila pada usia 12 bulan sampel telah menerima $1 \mathrm{x}$ imunisasi campak dan $3 \mathrm{x}$ imunisasi pentavalent dan dikatakan tidak lengkap apabila tidak menerima satu atau lebih imunisasi yang didapatkan pada anak dengan status imunisasi lengkap.

Kejadian RRI diukur menggunakan diagnosis ISPA yang tercatat dalam Sistem Informasi Manajemen Puskesmas (SIMPUS) Puskesmas Sibela. Dikatakan RRI apabila anak dalam satu tahun mengalami lebih dari 5 kali kejadian ISPA.

Status gizi dalam penelitian ini diukur sesuai WHO child growth standards. Data dikumpulkan dengan mengukur tinggi dan berat badan anak menggunakan timbangan dan medline. Data akhirnya diolah ke data nominal dikotomik menjadi anak dengan gizi normal yakni anak dengan indeks status gizi antara lebih dari -2 SD sampai kurang dari +2 $\mathrm{SD}$, diluar ini status gizi anak dikatakan tidak normal.

Kepadatan hunian diukur berdasarkan rasio antara total luas kamar di rumah dibandingkan dengan jumlah penghuni. Hunian dikatakan tidak padat apabila kepadatan hunian lebih dari atau sama dengan $8 \mathrm{~m}^{2}$ per orang. Variabel adanya perokok dalam rumah ditentukan apabila terdapat sekurang-kurangnya satu orang perokok aktif dalam rumah maka dinyatakan ada. Apabila tidak terdapat perokok dalam rumah maka dinyatakan tidak ada. Tingkat pendidikan ibu ditentukan berdasarkan jenjang pendidikan terakhir yang ditamatkan ibu atau pengasuhnya apabila responden tidak diasuh langsung oleh orang tuanya. Tingkat pendidikan dikatakan tinggi apabila ibu menamatkan pendidikan terakhir SMA/sederajat atau lebih tinggi dan tingkat pendidikan rendah apabila hanya menamatkan hingga SMP/sederajat atau lebih rendah.

Tingkat pendapatan keluarga dikatakan tinggi apabila pendapatan keluarga sama dengan atau lebih tinggi dari UMK Kota Surakarta yakni Rp.1.668.700,00. Tingkat pendapatan keluarga dianggap rendah apabila pendapatan keluarga kurang dari UMK Kota Surakarta. Data dari variabel kepadatan 
hunian, perokok dalam rumah, tingkat pendidikan ibu dan tingkat pendapatan keluarga didapatkan berdasarkan wawancara terhadap orang tua anak. Analisis data dilakukan menggunakan program SPSS dengan melakukan analisis univariat, bivariat (chi-kuadrat), dan multivariat (regresi logistik). Studi ini telah lulus uji kelaikan etik yang dilakukan oleh komisi etik penelitian kesehatan (KEPK) Fakultas Kedokteran UNS.

\section{HASIL}

Dari 48 Posyandu, terpilih 4 Posyandu sebagai cluster yang diteliti dengan jumlah subyek 125 orang yang berusia antara 2 sampai 5 tahun. Namun, subyek yang bersedia untuk ikut berpartisipasi dalam penelitian sebanyak 124 orang. Kemudian dari 124 subyek diketahui bahwa terdapat 3 orang yang termasuk kriteria eksklusi yaitu memiliki riwayat berat bayi lahir rendah. Sehingga, jumlah subyek penelitian yang dapat dianalisis sebanyak 121 orang. Karakteristik subyek penelitian dapat dilihat secara rinci dalam Tabel 1.

Dari 121 anak tersebut terdapat 95 anak $(78,51 \%)$ mendapatkan imunisasi lengkap dan 26 anak lainnya tidak mendapatkan imunisasi dasar secara lengkap ataupun tidak menerima sama sekali. Pemilihan imunisasi ini berdasarkan bahwa secara teori memiliki pengaruh terhadap kejadian ISPA. Pada orang tua anak yang tidak imunisasi lengkap dan tidak diimunisasi peneliti mewawancarai alasan terkait hal ini. Beberapa alasan seperti anak yang sakit selama jendela waktu pemberian imunisasi, pengetahuan orang tua terkait jadwal imunisasi, orang tua yang terlalu sibuk dan masalah keyakinan terkait imunisasi mendasari masih adanya anak yang belum mendapatkan imunisasi lengkap.

Terdapat 31 anak $(25,62 \%)$ mengalami kejadian RRI dalam penelitian ini. Sedangkan sisanya 90 anak hanya mengalami beberapa kejadian ISPA namun tidak sampai dikategorikan sebagai RRI. Data status gizi menunjukkan bahwa sebagian besar subyek berstatus gizi normal, sebanyak 105 anak $(86,78 \%)$ dan sisanya 16 anak (13,22\%) berstatus gizi tidak normal (Tabel 2). Dalam hal kepadatan ruang, terdapat 58 anak $(47,93 \%)$ tidur dalam ruangan yang tergolong padat dan 63 anak lainnya $(52,07 \%)$. Hal ini terjadi karena umumnya anak masih tidur bersama orang tuanya, bersama ibunya, bersama saudaranya, ataupun pada beberapa kasus dalam keluarga tersebut memang tidak memiliki kamar sehingga dalam satu ruangan rumah untuk tidur seluruh anggota keluarga (Tabel 2).

Tabel 1. Karakteristik demografi subyek penelitian

\begin{tabular}{lcc}
\hline Karakteristik & Frekuensi & Persentase (\%) \\
\hline Jenis Kelamin & & \\
$\quad$ Laki-laki & 63 & 52,07 \\
$\quad$ Perempuan & 58 & 47,93 \\
Usia Anak & & \\
$\quad 24-36$ bulan & 41 & 33,9 \\
$\quad 37-48$ bulan & 48 & 26,4 \\
$\quad 49-60$ bulan & 48 & 39,7 \\
Tingkat Pendidikan Ibu/Pengasuh & 19 & 15,71 \\
$\quad$ Rendah & 102 & 84,29 \\
$\quad$ Tinggi & & \\
Status Ekonomi Keluarga & 17 & 14,05 \\
$\quad$ <UMR & 104 & 85,95 \\
$\quad$ _UMR & &
\end{tabular}


Tabel 2. Karakteristik subyek penelitian berdasarkan variabel lain

\begin{tabular}{lcc}
\hline Karakteristik & Frekuensi & Persentase (\%) \\
\hline Status Imunisasi & & \\
$\quad$ Tidak lengkap & 26 & 21,49 \\
$\quad$ Lengkap & 95 & 78,51 \\
Kejadian RRI & 31 & 25,62 \\
$\quad$ RRI & 90 & 74,38 \\
$\quad$ Bukan RRI & & \\
Status Gizi & 105 & 86,78 \\
$\quad$ Normal & 16 & 13,22 \\
$\quad$ Tidak Normal & & \\
Kepadatan Hunian & 58 & 47,93 \\
$\quad$ Tidak Padat & 63 & 52,07 \\
$\quad$ Padat & & \\
Adanya Perokok Dalam Rumah & 68 & 56,20 \\
$\quad$ Ada & 53 & 43,80 \\
$\quad$ Tidak Ada & & \\
\hline
\end{tabular}

Dari hasil uji chi-kuadrat, didapatkan nilai signifikansi antara status imunisasi dengan kejadian RRI sebesar 0,000. Hal ini menunjukkan terdapat hubungan bermakna antara status imunisasi anak dengan kejadian RRI. Selanjutnya koefisien kontingensi (r) dari penelitian ini adalah 0,494 dengan nilai $\mathrm{p}=0,000$. Sehingga disimpulkan bahwa status imunisasi dasar yang tidak lengkap berhubungan dengan kejadian RRI dengan kekuatan korelasi yang cukup (table 3).

Dalam analisis multivariat dengan nilai $\mathrm{p}=0,000$ yang berarti dengan tingkat keyakinan 95 persen, terdapat minimal satu variabel bebas yang berpengaruh terhadap variabel terikat. Variabel bebas yang memiliki pengaruh terhadap variabel terikat dalam analisis ini adalah status imunisasi $(\mathrm{p}=0,000)$ dan variabel lainnya dianggap tidak berpengaruh secara statistik karena lebih besar dari 0,05 nilai $\mathrm{p}$ nya. Model regresi logistik yang dilakukan dalam penelitian ini dinyatakan sudah cukup mampu untuk menjelaskan data (sesuai) karena dalam Uji Hosmer dan Lemeshow nilai signifikansinya lebih besar dari 0,05 yakni 0,800 . Adapun dari tabel 5 dapat ditunjukkan bahwa model regresi logistik yang digunakan telah cukup baik, karena mampu menebak dengan benar 85,1 persen kondisi yang terjadi (Table 4).

\section{PEMBAHASAN}

\section{Hubungan Status Gizi dengan Kejadian RRI}

Status gizi dikumpulkan dengan mengukur tinggi badan dan menimbang berat badan anak. Data yang dikumpulkan selanjutnya dikalkulasi berdasarkan nilai $z$ score WHO child growth standards sehingga memungkinkan didapatkan tiga kategori berdasarkan BB/U, TB/U, dan BB/TB. Oleh karena tujuan penggunaan data ini dalam penelitian adalah digunakan untuk analisis regresi logistik dalam analisis multivariat yang mensyaratkan data yang diolah bersifat kategorik maka data yang didapatkan diubah menjadi data nominal dikotomik yakni gizi normal dan gizi tidak normal.

Studi oleh Hadiana et al. (2013) menunjukan adanya hubungan bermakna antara status gizi dan kejadian ISPA. ${ }^{9}$ Menurut Andarini et al. (2005) pada anak yang mengalami kurang gizi, pada tingkat ringan atau sedang masih dapat beraktifitas tetapi bila diamati dengan seksama badannya akan mulai kurus, stamina dan daya tahan tubuhnya pun menurun, sehingga mempermudah untuk terjadinya penyakit infeksi, sebaliknya anak yang menderita penyakit infeksi akan mengalami gangguan 
nafsu makan dan penyerapan zat-zat gizi sehingga menyebabkan kurang gizi. ${ }^{10}$ Status

Tabel 3. Hasil analisis bivariat tiap-tiap variabel bebas dengan kejadian RRI

\begin{tabular}{|c|c|c|c|c|c|c|}
\hline \multirow[t]{2}{*}{ Variabel bebas } & \multicolumn{2}{|c|}{ Kejadian RRI } & \multirow[b]{2}{*}{$\mathbf{O R}$} & \multirow[b]{2}{*}{$\mathbf{p}$} & \multirow[b]{2}{*}{$\begin{array}{l}\text { Nilai chi- } \\
\text { kuadrat }\end{array}$} & \multirow[b]{2}{*}{$\mathbf{r}$} \\
\hline & $\begin{array}{c}\text { Bukan } \\
\text { RRI }\end{array}$ & RRI & & & & \\
\hline \multicolumn{7}{|l|}{ Status imunisasi } \\
\hline Lengkap & 83 & 12 & 18,774 & 0,000 & 39,14 & 0,49 \\
\hline Tidak lengkap & 7 & 19 & & & & \\
\hline \multicolumn{7}{|l|}{ Status gizi } \\
\hline Normal & 78 & 27 & 0,963 & 0,951 & 0,004 & 0,006 \\
\hline Tidak normal & 12 & 4 & & & & \\
\hline \multicolumn{7}{|l|}{ Kepadatan hunian } \\
\hline Tidak padat & 45 & 13 & 1,385 & 0,438 & 0,601 & 0,070 \\
\hline Padat & 45 & 18 & & & & \\
\hline \multicolumn{7}{|c|}{ Perokok di dalam rumah } \\
\hline Tidak ada & 38 & 15 & 0,779 & 0,551 & 0,356 & 0,054 \\
\hline Ada & 52 & 16 & & & & \\
\hline \multicolumn{7}{|c|}{ Tingkat pendidikan ibu } \\
\hline Tinggi & 78 & 24 & 1,896 & 0,222 & 1,490 & 0,110 \\
\hline Rendah & 12 & 7 & & & & \\
\hline \multicolumn{7}{|c|}{ Tingkat pendapatan keluarga } \\
\hline$\geq \mathrm{UMR}$ & 76 & 28 & 0,582 & 0,417 & 0,660 & 0,074 \\
\hline$<\mathrm{UMR}$ & 14 & 3 & & & & \\
\hline
\end{tabular}

Tabel 4. Hasil analisis multivariat

\begin{tabular}{|c|c|c|c|c|c|}
\hline & \multirow{2}{*}{ B } & \multirow{2}{*}{ Sig. } & \multirow{2}{*}{$\operatorname{Exp}(B)$} & \multicolumn{2}{|c|}{$\begin{array}{c}95 \% \text { C I for } \\
\text { EXP (B) }\end{array}$} \\
\hline & & & & Lower & Upper \\
\hline \multicolumn{6}{|l|}{ Variabel Bebas } \\
\hline Status imunisasi & 3.058 & .000 & 21.289 & 6.589 & 68.783 \\
\hline Status gizi & .156 & .846 & 1.169 & .242 & 5.652 \\
\hline Kepadatan hunian & .038 & .942 & 1.039 & .369 & 2.927 \\
\hline Ada/tidaknya perokok & -.138 & .795 & .871 & .308 & 2.466 \\
\hline Tingkat pendidikan ibu/pengasuh & .548 & .491 & 1.730 & .363 & 8.241 \\
\hline Tingkat ekonomi keluarga & -1.563 & .113 & .209 & .030 & 1.444 \\
\hline Constant & -1.835 & .000 & 160 & & \\
\hline Uji Hosmer \& Lemeshow & 0,80 & & & & \\
\hline Nagelkerke R Square & 0,40 & & & & \\
\hline
\end{tabular}

Tabel 5. Classification plot

\begin{tabular}{lcrrr}
\hline \multirow{2}{*}{ Diamati } & \multicolumn{3}{c}{ Diprediksi } \\
\multicolumn{2}{c}{ Kejadian RRI } & Persentase benar \\
\hline \multirow{2}{*}{ Kejadian RRI } & Bukan RRI & 84 & 6 & 93.3 \\
& RRI & 12 & 19 & 61.3 \\
\hline
\end{tabular}


gizi memiliki hubungan bermakna dengan kejadian ISPA tetapi tidak memiliki hubungan bermakna dengan kejadian RRI karena ISPA baru dapat digolongkan sebagai RRI apabila terdapat lebih dari lima kali kejadian ISPA dalam satu tahun.

\section{Hubungan Kepadatan Hunian dengan Kejadian RRI}

Dalam penelitian ini terdapat 58 anak $(47,93 \%)$ tidur dalam ruangan yang tergolong padat dan 63 anak lainnya $(52,07 \%)$. Hal ini terjadi karena umumnya anak masih tidur bersama orang tuanya, bersama ibunya, bersama saudaranya, ataupun pada beberapa kasus dalam keluarga tersebut memang tidak memiliki kamar sehingga dalam satu ruangan rumah untuk tidur seluruh anggota keluarga.

Berdasarkan hasil analisis chikuadrat, kepadatan hunian tidak memiliki hubungan bermakna dengan kejadian RRI. Hasil ini bertentangan dengan penelitian serupa yang dilakukan oleh Winardi, et al. (2015) yang menunjukan adanya hubungan bermakna antara kepadatan hunian dengan kejadian ISPA. Studi dilakukan untuk melihat hubungan berbagai kondisi lingkungan dengan kejadian ISPA pada balita. ${ }^{11}$ Pada variabel kepadatan hunian, dikatakan padat apabila kepadatannya $<9 \mathrm{~m}^{2}$. Perbedaan hasil terjadi karena studi dilakukan Winardi, et al. mengamati pengaruh terhadap kejadian ISPA dan tidak lebih jauh dikelompokkan kedalam RRI.

\section{Hubungan Status Pendidikan Orang Tua dengan Kejadian RRI}

Dalam penelitian ini status pendidikan orang tua tidak memiliki hubungan yang bermakna dengan kejadian RRI. Studi serupa dilakukan oleh Ristiyanto (2015) menemukan adanya hubungan antara tingkat pendidikan formal orang tua dengan kejadian ISPA pada balita. $^{12}$

\section{Hubungan Tingkat Pendapatan Keluarga dengan Kejadian RRI}

Tingkat pendapatan keluarga memiliki hubungan yang tidak bermakna dengan kejadian ISPA. Hal ini senada dengan studi yang dilakukan oleh Nasution et al. pada tahun 2009 bahwa tidak didapatkan hubungan antara tingkat pendapatan keluarga, status gizi, tingkat pendidikan orang tua, dan tingkat kepadatan hunian dengan prevalensi ISPA. ${ }^{13}$

\section{Hubungan Adanya Perokok dengan Kejadian RRI}

Hasil dari studi menunjukkan hubungan yang tidak bermakna antara adanya perokok dengan kejadian RRI. Penelitian lainnya oleh Winardi et al. (2015) menemukan adanya hubungan antara asap rokok dengan kejadian ISPA pada balita. Menurut Mardjanis (2007), bahwa asap rokok dari perokok aktif memang bukan menjadi penyebab langsung kejadian penyakit ISPA pada anak balita, tetapi menjadi faktor tidak langsung yang diantaranya dapat menimbulkan penyakit paru-paru yang akan melemahkan daya tahan tubuh balita. ${ }^{11}$

\section{Hubungan Status Imunisasi dengan Kejadian RRI}

Dari analisis yang sudah dilakukan dapat disimpulkan bahwa status imunisasi yang tidak lengkap berpengaruh terhadap kejadian RRI. Hal ini terjadi karena pada anak yang mendapatkan imunisasi dasar secara lengkap memiliki kekebalan yang lebih baik terhadap beberapa penyakit yang dapat berkembang menjadi ISPA. Sebagaimana menurut satgas imunisasi IDAI (2011) sebagian kematian ISPA berasal dari jenis ISPA yang berkembang dari penyakit yang dapat dicegah dengan imunisasi seperti difteri, pertussis, Hib, dan campak. ${ }^{14}$ Sedangkan variabel lain secara statistik dianggap tidak berpengaruh. Hal yang mendasari hasil ini 
yakni pada status gizi, peneliti hanya mengambil data berat badan dan tinggi badan saat pengambilan data yang tidak mampu memberikan gambaran status gizi anak dalam satu tahun kebelakang. Seharusnya pengambilan data status gizi menggunakan metode penelitian cohort yakni pengambilan data status gizi selama satu tahun kedepan sehingga dapat tergambarkan lebih jelas interaksi antar variabel.

Pada tahun 2014 Sambominanga et al. melakukan penelitian serupa tentang hubungan antara pemberian imunisasi dasar lengkap dengan kejadian RRI. Penelitian dilakukan dengan menggunakan metode potong lintang dengan 56 sampel yang diambil menggunakan teknik quota sampling. Hasil penelitian menunjukkan tidak adanya hubungan antara status imunisasi dasar dengan kejadian RRI. ${ }^{15}$ Sementara itu, Agussalim (2012) mengamati hubungan pengetahuan, status imunisasi, dan keberadaan perokok dengan penyakit ISPA. Studi dilakukan menggunakan metode potong lintang terhadap 53 balita menunjukkan adanya hubungan antara status imunisasi dengan kejadian ISPA. ${ }^{16}$

Dari analisis yang sudah dilakukan dapat disimpulkan bahwa status imunisasi yang tidak lengkap berpengaruh terhadap kejadian RRI. Hal ini terjadi karena pada anak yang mendapatkan imunisasi dasar secara lengkap memiliki kekebalan yang lebih baik saat pengambilan data yang tidak mampu memberikan gambaran status gizi anak dalam satu tahun kebelakang. Seharusnya pengambilan data status gizi menggunakan metode penelitian cohort yakni pengambilan data status gizi selama satu tahun kedepan sehingga dapat tergambarkan lebih jelas interaksi antar variabel. menurut satgas imunisasi IDAI (2011) berpengaruh. ${ }^{14} \mathrm{Hal}$ yang mendasari hasil ini yakni pada status gizi, peneliti hanya mengambil data berat badan dan tinggi badan terhadap beberapa penyakit yang dapat berkembang menjadi ISPA. Sebagaimana

\section{Keterbatasan penelitian}

Keterbatasan pada penelitian adalah menggunakan metode potong lintang sehingga terdapat variabel lain seperti status gizi yang tidak terwakili dengan baik. Pada penelitian potong lintang data status gizi yang digambarkan hanya menggambarkan status gizi anak disaat itu dan tidak dapat menggambarkan keadaan gizi anak setahun kebelakang. Terkait kepadatan hunian, sebenarnya kamar tidur anak pada sampel umumnya memiliki luas yang telah memenuhi standar. Akan tetapi, umumnya anak di usia ini enggan untuk tidur sendiri (tidur bersama ibu atau saudaranya) sehingga nilai kepadatan hunian meningkat.

\section{KESIMPULAN}

Terdapat hubungan yang bermakna antara status imunisasi anak yang tidak lengkap dan terdapat hubungan yang lemah antara tingkat pendidikan ibu dengan kejadian RRI pada balita usia 2-5 tahun di Wilayah Kerja Puskesmas Sibela, Surakarta dengan nilai OR secara berurutan adalah $\mathrm{OR}=21,289$ dan $\mathrm{OR}=1,730$. Tidak terdapat hubungan yang bermakna antara kepadatan hunian $(\mathrm{p}=0,942)$, paparan asap rokok, dan tingkat pendapatan keluarga dengan kejadian RRI pada balita usia 2-5 tahun di Wilayah Kerja Puskesmas Sibela, Surakarta.

\section{UCAPAN TERIMAKASIH}

Ucapan terima kasih kami ucapkan kepada Balgis, dr., M.Sc., CM-FM, AIFM, Sp. Ak. selaku penguji penelitian ini.

\section{REFERENSI}

1. World Health Organization (WHO). World Health Statistics 2015. Luxembourg: WHO press; 2015. 
2. Kumar A, Ellis P, Arabi Y, Roberts D, Light B, Parillo JE, et al. Initiation of inappropriate antimicrobial therapy results in a fivefold reduction of survival in human septic shock. Chest Journal 2009; 136:1237-1248.

3. Badan Penelitian dan Pengembangan Kesehatan Kementerian Kesehatan RI (Kemenkes RI). Riset Kesehatan Dasar 2013. Jakarta: Kemenkes RI; 2013..

4. Jesenak M, Ciljakova M, Rennerova Z, Babusikova E, and Banovcin P. Reccurent Respiratory Infection in Children Definition, Diagnostic Approach, Treatment and Prevention. Intechopen 2011; 8:119-148.

5. Duijts L, Jaddoe V, Hofman A, dan Moll H. Prolonged and Exclusive Breastfeeding Reduces the Risk of Infectious Diseases in Infancy. Pediatrics. Illinois: American Academy of Pediatrics 2010; 126:e18-e25.

6. Jackson $\mathrm{S}$, Mathews $\mathrm{K}$, Pulanić $\mathrm{D}$, Falconer R, Rudan I, Campbell H, Nair H. Risk Factors for Severe Acute Lower Respiratory Infections In Children - A Systematic Review And Meta-Analysis. Croat Medical Journal 2013; 54:110-121.

7. Lestari C, Tjitra E, Sandjaja. Dampak Status Imunisasi Anak Balita di Indonesia Terhadap Kejadian Penyakit. Media penelitan dan Pengembangan Kesehatan 2009; XIX Suplemen II:S5-S12.

8. Mayor S. Acute Respiratory Infection Are World's Third Leading Cause of Death. BMJ 2010. [cited 2018 May 16] Available from https://www.bmj.com/content/341/bmj.c63 60.full

9. Hadiana S, Widodo P, Anang G. 2013. Hubungan Status Gizi Terhadap Terjadinya Infeksi Saluran Pernapasan Akut (ISPA) Pada Balita di Puskesmas Pajang Surakarta. Surakarta: Universitas Muhammadiyah Surakarta.

10. Andarini, S., Asmika., dan Noviana A. 2005. Hubungan antara status gizi dan tingkat konsumsi energi, protein, dengan frekuensi kejadian infeksi saluran pernapasan akut (ISPA) pada balita diwilayah kerja puskesmas gondanglegi, kecematan gondang legi kabupaten malang. Malang: Universitas Brawijaya.

11. Winardi W, Umboh J, Rattu A. 2015. Hubungan Antara Kondisi Lingkungan Rumah Dengan Kejadian Penyakit ISPA Pada Anak Balita di Wilayah Kerja Puskesmas Sario Kecamatan Sario Kota
Manado. Manado: Universitas Sam Ratulangi.

12. Ristiyanto R. 2015. Hubungan Antara Tingkat Pendidikan Formal dan Pengetahuan Orang Tua tentang ISPA pada Balita di Puskesmas Gatak. Surakarta: Universitas Muhammadiyah Surakarta.

13. Nasution K, Sjahrullah M, Brohet K, Wibisana K, Yassien M, Ishak L, Pratiwi L, Wawolumaja C, Endyarni B. 2009. Infeksi Saluran Napas Akut pada Balita di Daerah Urban Jakarta. Sari Pediatri Vol.11 No.4. Jakarta: Badan Penerbit Ikatan Dokter Anak Indonesia (BP-IDAI).

14. Satgas Imunisasi IDAI. 2011. Pedoman Imunisasi di Indonesia. Jakarta: IDAI

15. Sambominanga $\mathrm{P}$, Ismanto A, Onibala F. 2014. Hubungan Pemberian Imunisasi Dasar Lengkap dengan Kejadian Penyakit ISPA Berulang Pada Balita di Puskesmas Ranotana Weru Kota Manado. Manado: Universitas Sam Ratulangi.

16. Agussalim. 2012. Hubungan Pengetahuan, Status Imunisasi dan Keberadaan Perokok Dalam Rumah dengan Penyakit Infeksi Saluran Pernafasan Akut Pada Balita di Puskesmas Peukan Bada Kabupaten Aceh Besar. Banda Aceh: Jurnal Ilmiah Stikes U’Budiyah; Vol. 1 No.2. Pp: 1-11. 